\title{
Administrative and legal measures to stimulate entrepreneurship in agriculture
}

\author{
Saniyat Agamagomedova ${ }^{1, *}$, Yana Getman ${ }^{2}$, Vera Kolodkina ${ }^{2}$, Svetlana Zakirova ${ }^{2}$, and \\ Roman Ilyushin ${ }^{3}$ \\ ${ }^{1}$ Penza State University, Krasnaya str., 40, 460026 Penza, Russia \\ ${ }^{2}$ Rostov Branch of the Russian State University of Justice, Lenin str., 66. 344038 Rostov-on-Don, \\ Russia \\ ${ }^{3}$ Russian Academy of National Economy and Public Administration under the President of the \\ Russian Federation, Vernadsky prospect, 82, 119571 Moscow, Russia
}

\begin{abstract}
In the context of the theory of entrepreneurial ecosystems (EE), a set of administrative and legal measures that stimulate the development of entrepreneurship in agriculture have been identified and analyzed. These elements of $\mathrm{EE}$ are poorly studied in science, at the same time, administrative and legal measures to stimulate entrepreneurship in agriculture are positioned from the point of view of the development of the institution of state regulation in agriculture and can have a significant impact on all structural elements of EE. The authors have identified three models of state regulation of entrepreneurship in agriculture, one of which is the model of state stimulation of entrepreneurship in agriculture. State and non-state measures to stimulate entrepreneurship in agriculture are highlighted, the forms and levels of regulation are indicated in state regulation. The quantitative and qualitative growth of rural entrepreneurship subjects, the introduction of innovations, the formation of entrepreneurial values, the potential for solving modern problems of agricultural entrepreneurship are highlighted as the goals of state stimulation of entrepreneurship in agriculture. It is concluded that it is possible to single out an agricultural entrepreneurial ecosystem (AEE).
\end{abstract}

\section{Introduction}

Modern science positions entrepreneurship as a leading force in economic development, as a community of people, called upon to change their external socio-economic environment. Moreover, entrepreneurs themselves are able to change the conditions in which they function, and external factors can affect the development of entrepreneurship, act as incentives for entrepreneurial activity in certain industries. One of these factors is the state regulation of entrepreneurship.

Within the framework of the current theory of entrepreneurial ecosystems (EE), scientists also distinguish a number of elements, among which there are government institutions, in most cases they identify them with the regulatory framework and recognize

\footnotetext{
* Corresponding author: saniyat aga@mail.ru
} 
their impact on the development of EE [1]. There are very few special studies of the influence of administrative requirements and rules on the development of entrepreneurship in general, and particularly in certain areas of the economy. There is even less work related to administrative and legal measures to stimulate entrepreneurship in agriculture, in which entrepreneurship is certainly specific.

Scientists recognize the importance of partnerships and networks in farming, highlight certain value chains in agriculture, elements of which help farmers gain access to information about markets, government support measures and technologies that contribute to success in agricultural business [2]. Traditionally, agriculture is viewed as a low-tech sector with low dynamics, dominated by numerous small family businesses [3-4]. Singling out methods of making managerial decisions in agriculture, experts often combine the agricultural and ecological contexts of such management [5-6], and even highlight a special "eco-friendly approach in agriculture" [7].

In addition, entrepreneurship in agriculture is naturally associated with innovation and human resource development [6, 8]. Differentiating entrepreneurship in agriculture, scientists distinguish such types of it as social, gender, sustainable, natural entrepreneurship, recognizing that in most cases the sociality and sustainability of entrepreneurial initiative in agriculture are impossible without government support [9]. State measures to support entrepreneurship and stimulate its activity and social orientation become even more important in the context of compliance with safety requirements, especially food security [6]. Predicting the formation of a unified agricultural development strategy, scientists are increasingly talking about the role in the provision of public goods, while they designate two vectors of regulation: market and state and try to assess the degree of each in promoting the provision of public goods to the population [10]. In recent decades, studies devoted to the territorial (macroeconomic or regional) aspects of entrepreneurship in agriculture have become widespread, which is justified, since climatic, natural-geographical and territorial features determine the specifics of the structure of agriculture, its focus, the need for state support [8-11].

The review makes it possible to highlight the need to study the impact of measures of state support for entrepreneurship in agriculture on its condition and development, part of which are administrative and legal measures to stimulate such entrepreneurship. In most of the works devoted to the development of entrepreneurship in agriculture, the state influence on this area is indicated, however, the degree of such influence, its forms are not identified. At the same time, such measures can actively stimulate the so-called "entrepreneurial spirit" in agriculture, which is a rather "clumsy" branch of the economy. On the other hand, effective administrative and legal measures on the part of the state are designed to ensure environmental and food security in the creation and use of agricultural products, to protect the rights of both farmers and consumers of their goods and services.

\section{Models of state regulation of entrepreneurship in agriculture}

Various options for interaction between the state and agricultural entrepreneurs have developed historically. They can be grouped into three models of state regulation of entrepreneurship in agriculture. Of course, the selected models are not found in their pure form; any real model is a combination of the properties of various models. Nevertheless, we will give a brief description of them.

\subsection{Free agricultural market model}


The abandonment of a subsistence economy and the expansion of trade led to an increase in the level of freedom of agricultural entities, and gradually eliminated the mechanisms of arbitrary state intervention in private economic life, which was more typical of feudalism. Representatives of the institutional economy believe that the development of piracy and the widespread practice of smuggling played a certain role in the destruction of the traditional "overregulation" of the economic entity. They developed on the borders of feudal empires, and the clash of interests of several states and their unions prevented the establishment of full control over sea trade [12]. The model under consideration assumes no dependence between the state and producers of agricultural goods and services. It is believed that a similar model was formed in feudal Europe during the period of fragmentation, when the public power of the scattered European states was weak and unable to regulate the processes of production and exchange of agricultural products. Later, this theoretical model became widespread in the United States. In fact, the model under consideration projects the theory of the state as a "night watchman" on agricultural relations. It is assumed that state institutions not only do not interfere in relations in the field of agriculture, but also are not a participant in them. The processes of production, use and exchange of agricultural products occur regardless of the means and forms of state regulation, that is, we are talking about a free and state-independent market for agricultural products and services.

\subsection{Model of state management of agricultural production}

The disadvantages of the free agricultural market model are the lack of state guarantees for ensuring food and environmental security of a certain territory, as well as ensuring equality of agricultural entities.

As long as entrepreneurial farmers are free and independent, they do not work alone. Their activities are part of a complex environment that includes more people, including other farmers, wholesalers, exporters, carriers, engineers, geneticists, breeders, technicians, and processors. All of them are interconnected and each plays a certain role in the value chain [2]. The important role of the state in this model is:

1) establishing clear rules for conducting agricultural activities;

2) the establishment of criteria for the administrative and legal status of agricultural producers;

3) guaranteeing food and environmental safety of the territory;

4) regulation of the status and protection of land as the basis for the development of agriculture;

5) ensuring equality and freedom of competition in agricultural markets.

At the same time, special mention should be made of the equality of agricultural producers, regardless of their place of activity, climatic and geographical conditions of management. The idea of equality and justice in relations between people led to the principle of the equivalence of the exchange of goods, the idea of honest labor - to justify bourgeois entrepreneurship [12].

\subsection{Model of state incentives for entrepreneurship in agriculture}

Incentives are not entirely a new model of interaction between farmers and the state. Incentives for entrepreneurship are part of the agricultural government. The model of state incentives for entrepreneurship in agriculture involves the creation of conditions, the generation of factors that contribute to the quantitative and qualitative development of agricultural entrepreneurship. Traditionally, this model uses direct and indirect, state and non-state measures to stimulate entrepreneurial activity in agriculture. Examples of such measures include the introduction of a special risk insurance mechanism in agriculture; 
stimulating the use of innovation; development of mechanisms for providing soft loans to farmers; the use of leasing to improve the technical support of agricultural labor; simplification of barriers to entry into the market of agricultural products and services in this area, and others.

\section{Forms and levels of state regulation of entrepreneurship in agriculture}

\subsection{Forms of state regulation of entrepreneurship in agriculture}

Scientists distinguish two components of entrepreneurship: the management skills needed to start a business and make a profit, and the "entrepreneurial spirit". Both components are extremely important and interrelated. If management skills can be taught, then the "spirit of entrepreneurship" is not acquired [2]. State regulation of entrepreneurship in agriculture includes the mechanisms for acquiring of managerial skills in doing business in agriculture by real and potential farmers, as well as conditions for nurturing an "entrepreneurial spirit" in current and future farmers. The structure of measures to stimulate entrepreneurship in agriculture is shown in Figure 1.

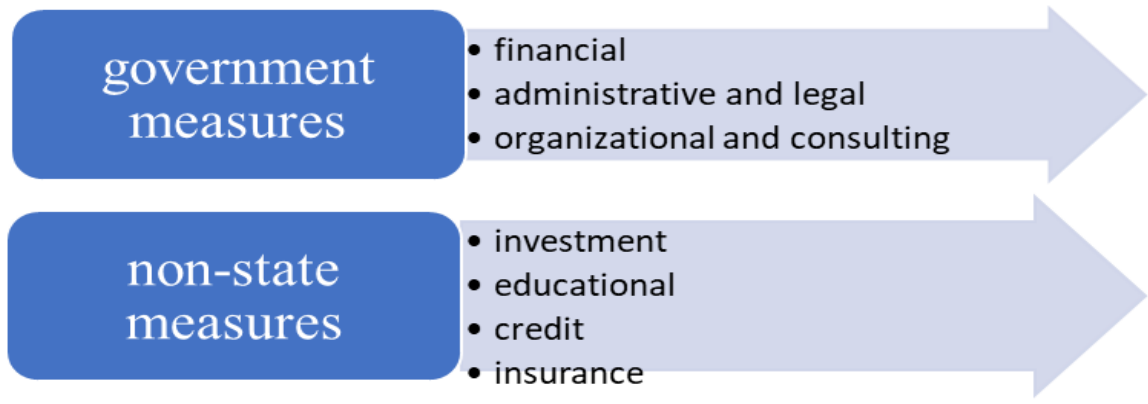

Fig. 1. Measures to stimulate entrepreneurship in agriculture

As forms of state regulation of entrepreneurship in agriculture, one should single out the legal regulation of requirements for agricultural production, as well as for the quality of goods and services offered by agricultural producers, the establishment of an optimal fiscal regime, the designation of clear limits of the administrative and legal statuses of entrepreneurs, the creation of special institutions for business development, subsidizing and lending to farms, educational programs to improve the qualifications of entrepreneurs and others. Naturally, each administrative-legal territory contributes to a certain set of forms of state regulation. For example, in the state regulation of Japan, the emphasis is on saving land resources and consolidating the labor force in agriculture [8].

\subsection{Levels of state regulation of entrepreneurship in agriculture}

Entrepreneurship, including agricultural entrepreneurship, is heterogeneous. Therefore, there are reasons to distinguish between different levels of state regulation of entrepreneurship in agriculture. So, we can distinguish large, medium and small businesses in agriculture. Scientists emphasize the best adaptability of small entrepreneurs, their courage in creating and using new varieties of plants and animal breeds, diversifying production. They are sensitive to the requirements of consumers of their goods and services [2]. In addition, the activities of small-scale farmers lead to poverty reduction in certain areas [13]. 
Interestingly, in studies of countries with economies in transition, scientists identify opportunities for grass-roots entrepreneurship [11]. In addition, it is generally accepted that natural entrepreneurship is increasingly being used as a way to facilitate the entry of small and medium-sized enterprises focused on co-innovation [9].

It is possible to single out entrepreneurs who are focused on exporting their products and focused on the national market. It is recognized that the sphere of foreign trade is freer from state regulation in comparison with the regulation of domestic turnover [12].

Entrepreneurship is also differentiated into the spheres of production and services, commercial, financial, intermediary, insurance and other types. In agricultural business, there is both a production form and a service activity, with the former one traditionally dominating. Regardless of the type of agricultural entrepreneurship, it is important to ensure equal conditions for economic entities operating in different territorial and climatic environments. Such equality is achieved, among other things, by state planning, targeted and socially oriented taxation, and the optimal balance of various sectors of agriculture. In addition, the differentiation of agricultural entrepreneurship continues and deepens, including through the emergence of new entrepreneurial cycles within existing firms [3].

The territorial levels of entrepreneurship cannot be ignored either. Certain territories, countries and regions require their own arsenal of state regulation tools. In particular, in modern Japan, state regulation of agriculture is aimed at saving agricultural land and providing a sufficient number of workers [8], in agriculture in transitional type of economy, the dominance of large international corporations is recognized [11].0

\section{Stimulation as a kind of state regulation of entrepreneurship in agriculture}

\subsection{Stimulation objectives}

The goals of stimulating entrepreneurship in agriculture is the quantitative and qualitative development of entrepreneurship, the introduction of innovations in agriculture. The latter is especially difficult, since it is believed that farms prefer "to do something better than others than to do something fundamentally new" [3]. However, in recent years, this characteristic of rural entrepreneurship has been transforming, mainly due to critical behavior and increased demands on consumers of agricultural goods and services (for example, the demand for environmentally friendly and safe food products by an increasingly wider population). According to scientists, such a transformation generates the emergence of qualitatively new agricultural enterprises, stimulates the introduction of innovations [3]. The authors draw attention to the close relationship between innovation, entrepreneurship and human resource development [8], highlight innovations to improve the efficiency of resource use for sustainable agriculture [6]. H. Dieleman, in connection with this, states the "quiet revolution" in agricultural entrepreneurship [14].

Stimulating entrepreneurship can also solve a number of problems in the modern agricultural sector. In developed countries, such problems include a decline in competitiveness and sustainability, an aging social stratum of farmers, a reduction and depletion of agricultural land [8]. In addition, one cannot but take into account the new problems for farmers associated with boycotts, the sanctions regime, restrictions on the freedom of circulation of agricultural products associated with coronavirus infection.

And, finally, the most important goal of state stimulation of entrepreneurship in agriculture is the formation, cultivation and preservation of the system of entrepreneurial values [15]. At the same time, these values should be enshrined in the current legislation, which ensures the development of entrepreneurial activity in agriculture. 


\subsection{Stimulation types}

It is necessary to highlight various types of government incentives for entrepreneurship in agriculture.

First, the state at the national and regional levels develops and implements a strategy for the development of entrepreneurial and other economic activities in a certain territory for a specific period of time. We are talking about export, innovation strategies, strategies of socio-economic development, strategies for digitalization of certain sectors of the economy, etc. In some countries, for example, this is the Strategy for the development of telecommunications infrastructure and "electronic society" [15].

Secondly, the development of information and communication technologies, digitalization of public services are closely and directly related to the stimulation of entrepreneurship. Moreover, we are talking not only about entrepreneurship in the IT sphere, but also other types of entrepreneurship, including farming. Examples of entrepreneurship development in individual countries indicate that a significant contribution to the growth of human capital, knowledge base and the creation of structural conditions for the development of energy efficiency is made by the state (through infrastructure solutions and educational technologies) and successful businessmen who serve as an example for others [15].

Third, it is the creation of specialized agricultural clusters in which successful cooperation between agriculture, trade and industry, networking, franchising and corporate innovation is ensured using limited regional resources [8].

Fourth, the implementation of optimal mechanisms that combine the historical traditions of family small-scale farming [3-4] and innovative technologies for the creation, preservation and circulation of agricultural products.

Fifth, it is necessary to separately highlight the types of state incentives for entrepreneurship in agriculture, associated with the formation of entrepreneurial skills in universities and agricultural universities. Universities have traditionally been perceived as an essential element of energy efficiency; they play a large role in generating new entrepreneurs.

\subsection{Administrative and legal incentives}

Administrative and legal measures should be understood in two senses: in the broad (all management measures, the activities of the government in general) and in the narrow (directive decisions of state authorities) senses. We are closer to the first, broader understanding of administrative and legal measures to stimulate entrepreneurship in agriculture. Figure 2 shows the main types of administrative and legal measures in the area under consideration, to which we refer status, organizational, consultative measures and preferences. 


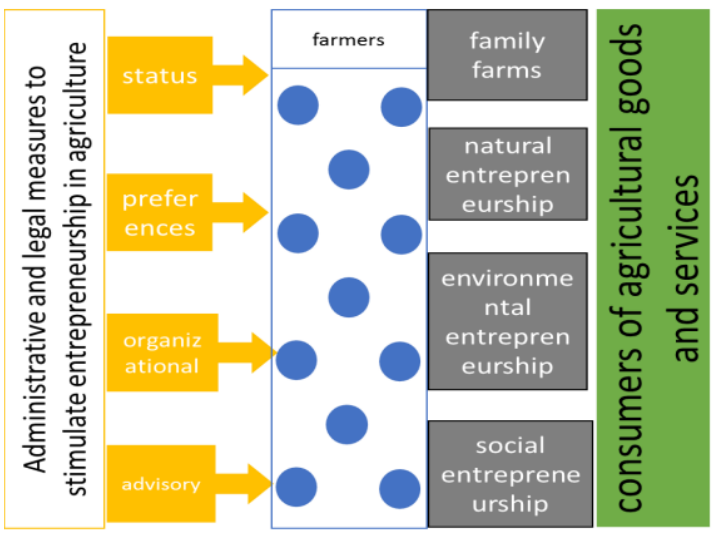

Fig. 2. Administrative and legal measures to stimulate entrepreneurship in agriculture

Status measures include measures based on the recognition and protection of a certain status for entrepreneurs in agriculture. This can be the status of a representative of a small or medium-sized entrepreneur, the status of a peasant farm, etc. This status allows you to reduce the measures of legal responsibility when detecting violations in activities, to obtain certain simplifications when going through administrative procedures, etc.

Organizational measures include measures to assist in entering markets, assistance in using the infrastructure necessary for the full functioning of farms.

Consulting measures are related to the education of entrepreneurs in the field of legal regulation, financial (tax, banking and other) components of agricultural business.

Preferential measures are closely related to the measures outlined above. The state stimulates the development of entrepreneurship in agriculture, including by providing a more simplified regime for the implementation of this economic activity. We are talking about preferential mechanisms for financial assistance, insurance, lending, acquisition and renewal of technical agricultural parks, etc.

All the incentive measures identified are based on the current legislation, more precisely, on those of its sectors that are associated with the implementation of agricultural activities (Fig. 3).

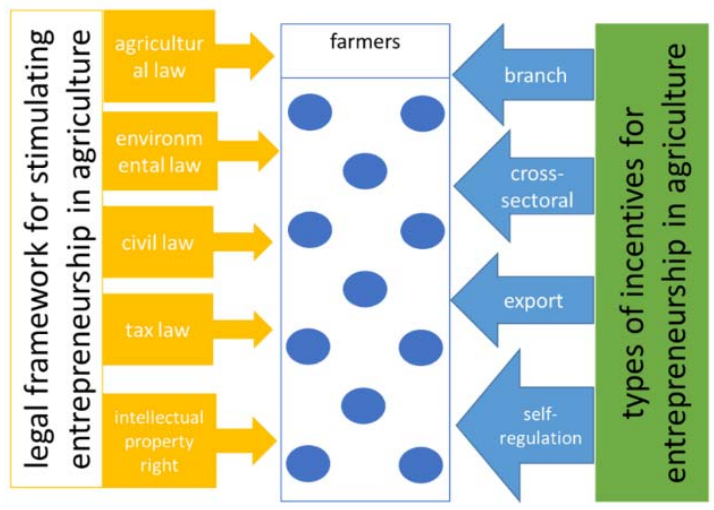

Fig. 3. Regulatory framework and types of administrative incentives for entrepreneurship in agriculture

Scientists recognize that institutions conducive to the development of entrepreneurship are generated primarily through changes in the legal system. For example, the development 
of credit, insurance, arbitration, patent and other mechanisms in the trade turnover contributed to its activation and expansion [12].

It should be noted that, in addition to regulatory legal acts, the effectiveness of the administrative measures taken is influenced by the strategic support of state activities. We are talking about various kinds of strategies for individual areas of development (strategies for the socio-economic development of the territory, export strategies of the regions, the strategy for the development of the regional cluster policy, etc.). 4.

The results of state incentives for agricultural entrepreneurship are presented in Figure

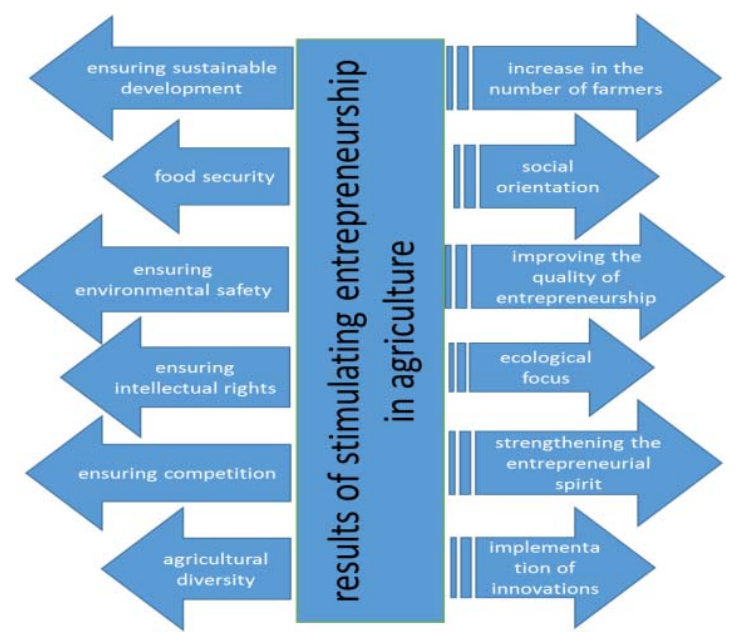

Fig. 4. Results of stimulating entrepreneurship in agriculture

These results reflect both the private rights and freedoms of entrepreneurs and basic government priorities in agriculture. Increasingly, the issues of entrepreneurship in agriculture are associated with food security, environmental safety, Sustainable Soil Management [6]. Taking these factors into account allows us to talk about the formation and maintenance of the highest level of entrepreneurship in agriculture - "entrepreneurship for the implementation of new opportunities" [15], which are designed to ensure both the private interests of farmers and consumers of agricultural goods and services, and public interests (state, business overall competition).

\subsection{Stimulation in the entrepreneurial ecosystem}

Administrative and legal measures to stimulate entrepreneurship in agriculture cannot be considered in isolation, outside of the whole EE. We believe that a special type of EE can be distinguished - an agricultural entrepreneurial ecosystem. It includes a number of components, united by the specifics of agricultural entrepreneurship (agricultural entrepreneurial ecosystem) (AEE). It is shown in Figure 5. Of course, AEE is developing dynamically, its components are also transformed under the influence of internal and external factors. So, according to scientists, in a number of countries, foreign direct investment in entrepreneurship has been replaced by venture financing, which expands from the minimum start-up capital to millions invested through seed funds, and the cycle of creating new products is reduced from 5-7 to 1-3 years [15]. All this testifies to the maturity of the ecosystem.

An increasingly important component of AEE is the results of intellectual activity related to breeding achievements and nanotechnology-based tools in the field of genetic 
improvement of crop and livestock products. The latter are an indispensable attribute of sustainable agriculture, which requires both regulatory support and safety expertise [7].

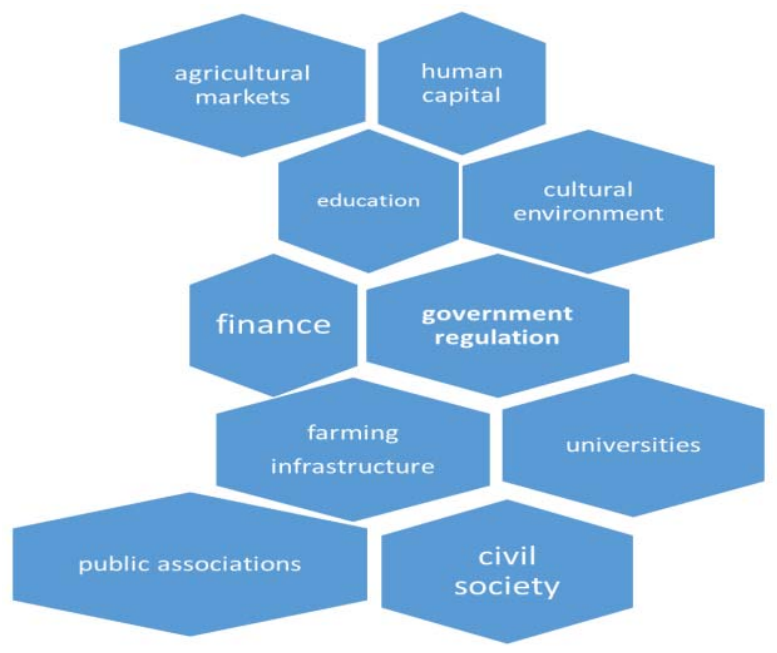

Fig. 5. Agricultural entrepreneurial ecosystem

Different stages of ecosystem evolution give rise to different entrepreneurial opportunities. And here such aspects as the state's will, political orientation and administrative and legal support for the generation of entrepreneurial values in society are important.

\section{Conclusions}

Administrative and legal measures to stimulate entrepreneurship in agriculture are an integral part of state regulation of the agricultural sector. Neither these measures themselves, nor government regulation of agriculture in general, can be considered outside the entrepreneurial ecosystem, taking into account its agricultural specificity, which we called the agricultural entrepreneurial ecosystem (AEE). Its structural element is state regulation (regulatory framework) in the field of agriculture, and sustainability and environmental friendliness are essential properties. The word combination "sustainable agriculture" is firmly entrenched in the scientific terms circulation and is associated with its use for the development of environmentally sustainable and profitable food production systems [6-7]. The modern AEE combines incentives for innovation [11] and at the same time agricultural dynasties [3-4]. All the incentive measures identified are based on the current legislation related to the implementation of agricultural activities, as well as strategies for the socio-economic and other development of certain territories. Administrative and legal measures to stimulate entrepreneurship in agriculture actively influence the entire structure of the AEE.

Government intervention in agriculture and the stimulation of entrepreneurship in it will increasingly be associated with the provision of public goods for the population. And it is the quality of these benefits that will determine the ratio of state and market regulation in the agricultural sector [10].

Scientists are actively exploring the potential of nanomaterials to protect the health of crops, plants and animals, to increase the productivity of agricultural labor, the quality of goods and services provided by farmers [7]. They increasingly highlight the link between agricultural entrepreneurship, sustainability and social entrepreneurship [9]. 
In conclusion, it should be noted that the acceleration of business development leads to the mutual penetration of various ecosystems. Success stories of certain businesses contribute to the growth of confidence in the business environment, which in turn has a positive effect on investment activity and the creation of new enterprises that more effectively use the opened windows of opportunities [15], in the opening of which is involved not only business, but also the state.

\section{References}

1. http://www3.weforum.org/docs/WEF_EntrepreneurialEcosystems_Report_2013.pdf (last accessed 2021/02/03)

2. D. Kahan, Entrepreneurship in farming. Food and agriculture organization of the united nations, Rome, $136 \quad$ (2012) http://www.fao.org/uploads/media/5EntrepreneurshipInternLores.pdf

3. T. Lans, P. Seuneke, L. Klerkx, Agricultural Entrepreneurship. In: Carayannis E.G. (eds) Encyclopedia of Creativity, Invention, Innovation and Entrepreneurship (Springer, Cham 2020) https://doi.org/10.1007/978-3-319-15347-6_496

4. J. Suess-Reyes, E. Fuetsch, The future of family farming: aliterature review on innovative, sustainable andsuccession-oriented strategies, Journal of Rural Studies 47, 117-140 (2016) https://doi.org/10.1016/j.jrurstud.2016.07.008

5. J. Berbel, Th. Bournaris, B. Manos, N.F. Matsatsinis, D. Viaggi, Multicriteria Analysis in Agriculture. Current Trends and Recent Applications., Springer International Publishing 10, 321 (2018) DOI: 10.1007/978-3-319-76929-5

6. M. Farooq, M. Pisante, Innovations in Sustainable Agriculture, Springer International Publishing (2019) DOI: 10.1007/978-3-030-23169-9

7. P. Ramesh, N. Chauhan, N.K. Chittaranjan, Nanoscience for Sustainable Agriculture, Springer International Publishing 15, 711 (2019) DOI: 10.1007/978-3-319-97852-9

8. K. Akira, Entrepreneurship and Innovation in Japanese Agriculture, Springer Singapore 10, 170 (2019) DOI: 10.1007/978-981-13-8055-6

9. V. Ratten, P. Jones, V. Braga, C.S. Marques, Subsistence Entrepreneurship. The Interplay of Collaborative Innovation, Sustainability and Social Goals, Springer International Publishing 8, 237 (2019) DOI: 10.1007/978-3-030-11542-5

10. F. Vanni, Agriculture and Public Goods. The Role of Collective Action, Springer Netherlands 15, 150 (2014) DOI: 10.1007/978-94-007-7457-5

11. A. Sauka, A. Chepurenko, Entrepreneurship in Transition Economies. Diversity, Trends, and Perspectives, Springer International Publishing 13, 444 (2017) DOI: 10.1007/978-3-319-57342-7

12. R. Nureyev, The Genesis of Capitalism: The Role of Entrepreneurship-friendly Institutions, Terra Economicus 9(4), 122-141 (2011)

13. C. Poulton, A. Dorward, J. Kydd, The future of small farms: new directions for services, institutions, and intermediation, World Dev 38, 1413-28 (2010)

14. H. Dieleman, Urban agriculture in Mexico City: balancing between ecological, economic, social and symbolic value, Journal of Cleaner Production, 163 (2016) DOI: 10.1016/j.jclepro.2016.01.082

15. Y. Trabskaja, T. Mets, Ecosystem as the Source of Entrepreneurial Opportunities, Foresight and STI Governance 13(4), 10-22 (2019) DOI: 10.17323/25002597.2019.4.10.22 